\title{
Tuberculous Appendicitis in a Child
}

\section{Bir çocuk Olguda Tüberküloza Bağlı Apendisit}

\author{
Gülsüm İclal Bayhan ${ }^{1 \star}$, Gönül Tanır ${ }^{2}$, Türkan Aydın Teke ${ }^{2}$ \\ ${ }^{1} Y \ddot{z}$ züncü Yal Üniveristesi T⿰力 Fakültesi, Cocuk Enfeksiyon Hastalıklar Bilim Dal, Van \\ ${ }^{2}$ Dr Sami Ulus Kadın Doğum Çocuk Sağhuğı ve Hastalıkları Eğitim ve Araştırma Hastanesi, Çocuk Enfelesiyon \\ Hastallklar Kliniği, Ankara
}

\begin{abstract}
Tuberculosis (TB) remains among the most important infectious diseases worldwide. Although Mycobacterium tuberculosis is readily aerosolized from the environment and usually leads to pulmonary disease, TB can involve any organ of the body, and abdominal TB is a form of extrapulmonary TB. Appendicitis is a very rare presentation of abdominal TB. Herein we present an 8year-old female patient diagnosed as TB appendicitis that was treated with anti-TB medication and surgical intervention.
\end{abstract}

Key Words: Tuberculosis, Mycobacterium tuberculosis, appendicitis, child

\begin{abstract}
ÖZET
Tüberküloz (TB) halen tüm dünyada en önemli enfeksiyon hastalıklarından biridir. Mycobacterium tuberculosis genellikle pulmoner hastalığa yol açmakla birlikte, TB vücutta tüm organları tutabilmektedir. Apendisit abdominal TB' nin çok nadir görülen bir formudur. Biz burda TB apendisiti tanısı alan cerrahi ve anti-TB tedavi ile düzelen sekiz yaşında kız olguyu sunduk.
\end{abstract}

Anahtar Kelimeler: Tüberküloz, Mycobacterium tuberculosis, apandisit, çocuk

abdominal pain, fever, nausea, vomiting, and anorexia. Upon examination acute appendicitis was diagnosed and appendectomy was subsequently performed. The patient had an uncomplicated postoperative course and was discharged on post surgery day 3. Pathologic evaluation of the appendectomy specimen showed granulomatous inflammation with caseification necrosis. The patient was then referred to our hospital with the preliminary diagnosis of tuberculosis for further evaluation three months after surgery.

At presentation the patient's physical examination findings were normal. The family history of TB was negative, as was TB screening of all household members. The patient did not have a BCG scar. Complete blood count, serum biochemical findings, and the erythrocyte sedimentation rate were normal. Tuberculin skin test (TST) was $15 \mathrm{~mm}$. Interferon gamma release assay (IGRA) (QuantiFERON-TB Gold) was positive, and chest $\mathrm{X}$-ray and thoracic computed tomography (CT) were normal. Abdominal CT showed multiple calcified mesenteric and paraaortic lymphadenopathies (LAPs). TB appendicitis was diagnosed based on positive TST and QuantiFERON-TB Gold test results, abdominal

An 8-year-old female originally presented to hospital other than ours with a 3-days history of 
CT findings, and histopathological findings of the appendix.

Anti-TB therapy with isoniazid, rifampin, and pyrazinamide was commenced. Because of a persistent elevated uric acid level pyrazinamide was changed to ethambutol. After two months of triple anti-TB therapy, ethambutol was withdrawn, and isoniazid and rifampin were continued for 4 more months. At the completion of the anti-TB therapy the patient was symptom free. Abdominal ultrasonography (USG) showed that calcified LAPs persisted. At 4 years post anti-TB therapy the patient was symptom free and her abdominal USG findings were normal.

\section{Discussion}

Abdominal TB accounts for $10 \%$ of all pediatric cases of TB. The gastrointestinal tract, peritoneum, lymph nodes, or visceral organs can be involved in abdominal TB. There are 3 ways of developing TB appendicitis; mycobacterial direct extension from adjacent organs, mycobacterial entry via infected ingested food, and mycobacterial entry via the blood stream from a focus in a distant organ or lymph nodes $(3,4)$. The most common forms of abdominal TB are peritoneal and lymph node TB. Generally, lymph node involvement accompanies other forms $(5,6)$. Although the ileocecal region is involved in $75 \%$ of abdominal TB cases, primary involvement of the appendix is very rare $(0.6 \%-2.9 \%)(7)$. In a study that included all surgically treated TB appendicitis cases from January 1995 to December 2009 the overall cumulative incidence of TB appendicitis was $0.08 \%$ $(0.2 \%$ all of TB cases and $8.6 \%$ of all abdominal TB cases) (8). A study that analyzed 870 appendicular specimens obtained over a 10 -year period reported that the prevalence of TB appendicitis was $2.9 \%(\mathrm{n}=$ 26). The researchers divided TB of the appendix into primary and secondary forms, based on the absence or presence, respectively, of a related TB focus elsewhere in the body; 10 cases were primary and 16 were secondary TB appendicitis. In all, 4 of the 10 primary TB cases presented as acute appendicitis, whereas 6 had a history of recurrent episodes of pain. In all 26 cases appendicitis TB was diagnosed based on histopathological findings (3). The presented case of TB appendicitis had acute onset, but no extraabdominal involvement; therefore, she was considered to have had primary TB appendicitis.

The clinical presentation of TB appendicitis is non-specific. Generally, medical history, clinical examination, and laboratory investigations do not yield findings that can differentiate appendicitis of different etiologies from that of TB origin (8). It was reported that only $14 \%$ of abdominal TB patients manifest features of pulmonary TB in chest X-rays (7). In cases accompanied by pulmonary $\mathrm{TB}$ the presence of abdominal symptoms and signs with a high index of suspicion make diagnosis of TB appendicitis easier (9). In contrast to secondary abdominal TB, primary cases do not have radiological findings characteristic of TB and a presumptive diagnosis is especially difficult to make. In most cases of TB appendicitis diagnosis cannot be made prior to histopathological examination, which almost always occurs post surgery. In such cases anamnesis, including contact with active TB, and TST and IGRA results are critically important $(8,9)$. The presented patient did not have pulmonary involvement and TB appendicitis was diagnosed via histopathologic examination, which was supported by TST and QuantiFERON-TB Gold results, and imaging findings of abdominal TB.

In patients with TB appendicitis surgery is often necessary and specific anti-TB therapy must be initiated as soon as possible (9). TB appendicitis is treated as abdominal TB. The prognosis of abdominal $\mathrm{TB}$ is usually good with anti-TB treatment (10). It was reported that due to late initiation of anti-TB treatment an ileocutaneous fistula developed that required a laparotomy and fistula excision (8). The presented patient fully recovered without complications following surgery and early commenced of anti-TB treatment.

In conclusion, although TB appendicitis is rare, when diagnosed and treated in a timely manner the prognosis can be favorable. Concomitant other organ system TB must be explored via appropriate investigations. Clinicians must be aware that M. tuberculosis can cause primary or secondary appendicitis.

\section{References}

1. WHO Global tuberculosis report 2012. http://www.who.int/tb/publications/global_report/ gtbr12_main.pdf 20/03/3013 (Erişim tarihi 15 temmuz 2013).

2. Göçmen A, Cengizlier R, Özçelik U, Kiper N, Şenuyar R. Childhood tuberculosis: a report of 2205 cases. Turk J Ped 1997; 39(2): 149-158.

3. Agarwal P, Sharma D, Agarwal A, Agarwal V, Tandon A, Baghel KD, et al. Tuberculous appendicitis in India. Trop Doct 2004; 34(1): 36-38.

4. Aston NO. Abdominal tuberculosis. World J Surg 1997; 21(5): 492-499. 
5. Tinsa F, Essaddam L, Fitouri Z, Brini I, Douira W, Ben Becher $\mathrm{S}$, et al. Abdominal tuberculosis in children. J Pediatr Gastroenterol Nutr 2010; 50(6): 634-638.

6. Shah I, Uppuluri R. Clinical profile of abdominal Tuberculosis in children. Indian J Med Sci 2010; 64(5): 204-209.

7. Elamurugan TP, Sivashanker M, Kumar SS, Muthukumarassamy R, Kate V. Primary tuberculous appendicitis presented with caecal perforation: a case report. Asian Pac J Trop Med 2012; 5(10): 834-836.
8. Chong VH, Telisinghe PU, Yapp SK, Chong CF. Tuberculous appendix: a review of clinical presentations and outcomes. Singapore Med J 2011; 52(2): 90-93.

9. Barbagallo F, Latteri S, Sofia M, Ricotta A, Castello G, Chisari A, et al. Appendicular tuberculosis: the resurgence of an old disease with difficult diagnosis. World J Gastroenterol 2010; 16(4): 518-521.

10. Nam SH, Kim JS, Kim KH, Park SJ. Primary tuberculosis appendicitis with mesenetric mass. J Korean Surg Soc 2012; 82(4): 266-269. 